\title{
Molecular and Morphological Investigation of Ornamental Liriopogons
}

\author{
Mwamburi Mcharo, ${ }^{1}$ Edward Bush, ${ }^{2}$ Don La Bonte, ${ }^{3}$ and Catherine Broussard ${ }^{4}$ \\ Department of Horticulture, Louisiana State University Agricultural Center, 137 J.C. Miller Hall, Baton \\ Rouge, LA 70803 \\ Lowell Urbatsch ${ }^{5}$ \\ Louisiana State University Herbarium and Biological Sciences Department, 202 Life Sciences Building, \\ Louisiana State University, Baton Rouge, LA 70803
}

\begin{abstract}
AdDITIONAL INDEX WORDS. Liriope spp., Ophiopogon spp.
ABSTRACT. Eighteen commercial taxa in genera Liriope and Ophiopogon were evaluated genetically and morphologically. Three hundred and forty-four Amplified Fragment Length Polymorphism (AFLP) markers were identified and used in the analysis. Relatedness among taxa was estimated by analyzing the AFLP data using the Dice coefficient of similarity and UPGMA methods. The molecular analysis revealed relatively no genetic differentiation among the taxa ascribed to their respective genera, Liriope and Ophiopogon, based on morphological assessment of floral structure. Greater than $95 \%$ of the total genetic variability present was attributed to within group effects using various grouping strategies among the taxa. Among group effects were correspondingly low and not significant $(P \leq 0.05)$. Results suggest an indistinguishable genetic relationship may exist in the tribe Ophiopogonae between what is currently ascribed as two distinct genera.
\end{abstract}

Liriopogons (Convallariaceae tribe Ophiopogoneae Endl.) are the most important clonal ground covers sold by the nursery industry in the southeastern United States. The term liriopogon proposed by Skinner (1971) collectively represents ornamentals in the genera Liriope Lour. and Ophiopogon Ker-gawl. (aztecgrass, lilyturfs, monkeygrass, and mondograss) and denoted an underlying morphological similarity between the two genera. For example, the popular aztecgrass is referred to commonly as a Liriope sp., but in actuality it is identified taxonomically as an Ophiopogon sp. (Adams, 1989). This similarity has led to industry-wide misidentification of genera and putative clones possessing multiple trade names (Fantz, 1994).

The industry widely regards cultivars in Liriope as possessing evergreen grasslike leaves, erect flowers with a superior ovary (Adams, 1989), and berrylike, fleshy black fruit (Liberty Hyde Bailey Hortorium, 1976). Species in the genera Ophiopogon possess narrow, evergreen grasslike leaves, drooping flowers with an inferior ovary (Adams, 1989), and a blue berrylike fruit (Bailey and Bailey, 1976). Arecent taxonomic treatment of the Convallariaceae differentiated the genera based mostly on flower part insertion (Conran and Tamura, 1998). Flowers of Liriope are hypogynous with the petals inserted around the base of the gynoecium, and slightly zygomorphic (bilateral symmetry). Seeds are blackish. Flowers of Ophiopogon are perigynous, i.e., the petals are attached to a cuplike hypanthium which arises round the base of the gynoecium, and actinomorphic (radial symmetry) (Fig. 1). Seeds are blue. In contrast, Rudall et al. (2000) uses hemi-epigynous to describe Ophiopogon flowers. The genus Peliosanthes Andrews shares these later characteristics and represents a putative third genus in

Received for publication 8 Nov. 2002. Approved for publication 20 Mar. 2003 Approved for publication by the director of the Louisiana Agricultural Experiment Station as manuscript number 02-34-0720. This research was supported by funds from state and matching funds allocated to the Louisiana State University Agricultural Center.

${ }^{1}$ Graduate student.

${ }^{2}$ Associate professor.

${ }^{3}$ Professor; to whom reprint requests should be addressed.

${ }^{4}$ Graduate student.

${ }^{5}$ Associate professor.
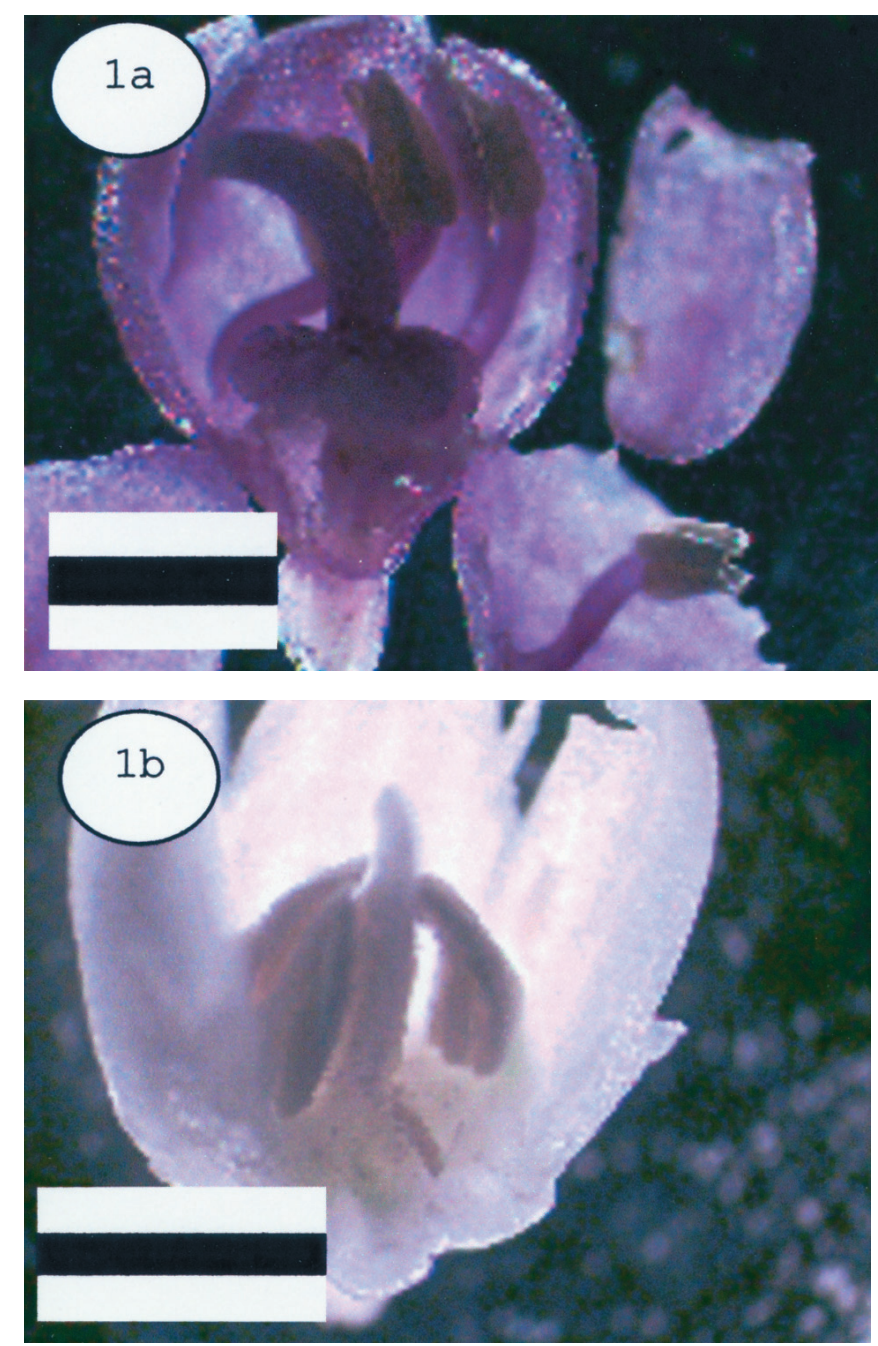

Fig. 1. Photomicrographs showing flower morphology of Liriope sp. and Ophiopogon sp.: (top) 'Royal Purple' (Liriope sp.) showing a hypogenous ovary insertion, (bottom) aztecgrass (Ophiopogon sp.) showing a perigynous ovary insertion. Bar $=1.0 \mathrm{~mm}$. 
Ophiopogoneae. Peliosanthes spp. have a corolla (inner set of floral leaves) whereas Ophiopogon spp. do not. Further refinement to species, e.g., Liriope spicata Lour., is more daunting, requiring mostly cellular level characterization (Cutler, 1992). Cultivaridentification is difficult and confounded by inconsistent naming.

Molecular characterization is an approach useful in assigning cultivars or clones to genera and identifying unique banding profiles capable of fingerprinting cultivars for definitive identification. To date, no reports exist in the literature using a molecular approach for these genera, notwithstanding a systematic investigation of the Convallariaceae by Rudall et al. (2000). Single accessions of the aforementioned genera were included in broader molecular and morphological analyses of Convallariaceae. Rudall et al. (2000) suggested that just Liriope and Ophiopogon belong in Ophiopogonae.

The objective of the present study was to use a combination of morphological descriptors and DNA fingerprinting to differentiate common industry taxa to the proper genera, to describe the extent of genetic similarities among these taxa, and to identify possible duplicate taxa.

\section{Materials and Methods}

Plant Material. Clones of 12 common industry cultivars (Big Blue, Christmas Tree, Densiflora, Evergreen Giant, John Birch, King Felix, Monroe White, Royal Purple, Samantha, Silver Dragon, Silver Midget, and Variegata), three clones referred to by their common name (aztecgrass, black mondo, and mondograss), two clones referred to by their cultivar-group name (minimondo and variegated mondo), and one clone referred to by its species ( $L$ spicata or spicata) were collected from nurserymen in Louisiana or from an in situ collection at Louisiana State University Agricultural Center, Burden Research Station, Baton Rouge, for inclusion in the study. The term taxa collectively represent cultivars, common names, cultivar-group names, and specie in this study. From June through August 2002, inflorescences were collected, preserved in FAA (ethanol $47.5 \%$, glacial acetic acid $5 \%$, formaldehyde 4 $\%$, and water $43.5 \%$ ) solution for later microscopic characterization. Also, voucher specimens were prepared and deposited in the Louisiana State University herbarium.

Plant DNA extraction. Young leaves were harvested, freezedried, and stored at $-20{ }^{\circ} \mathrm{C}$ until needed. Total DNA was isolated from $100 \mathrm{mg}$ of leaf tissue using the Genelute plant genome kit (Sigma-Aldrich Inc., St. Louis, Mo.).

AFLP ANALYSIS. Techniques for amplified fragment length polymorphism (AFLP) fingerprinting were adapted from those described by Vos et al. (1995). In total, $0.08 \mu \mathrm{g}$ of total genomic DNA from each sample was double-digested with 1.25 units each of a mixture of EcoRI and MseI (AFLP Core Reagent Kit, Gibco BRL, Gaithersburg, Md.) in $5 \times$ reaction buffer $[50 \mathrm{~mm}$ ris- $\mathrm{HCl}$ ( $\mathrm{pH} 7.5), 50 \mathrm{~mm} \mathrm{Mg}$-acetate, $250 \mathrm{~mm} \mathrm{~K}$-acetate] in a final volume of $6.25 \mu \mathrm{L}$. The reaction was incubated at $37^{\circ} \mathrm{C}$ for $3 \mathrm{~h}$. Then 6 $\mu \mathrm{L}$ of a mixture containing EcoRI and Mse I adapters [EcoRI/Mse] adapters, $0.4 \mathrm{mmATP}, 10 \mathrm{~mm}$ Tris- $\mathrm{HCl}$ (pH 7.5), $10 \mathrm{~mm} \mathrm{Mg}$-acetate, $50 \mathrm{~mm} \mathrm{~K}$-acetate, 0.25 units of T4 DNA ligase] were added and the reactions were incubated at $18{ }^{\circ} \mathrm{C}$ overnight. Samples were subsequently diluted $1: 10$ with TE buffer and stored at $-20^{\circ} \mathrm{C}$.

The preselective PCR amplifications were performed in $13 \mu \mathrm{L}$ reaction volumes each of which contained $10 \mu \mathrm{L}$ preamplification primer mix, $1.5 \mu$ Ldiluted adapter-ligated genomic DNA, 1.25 unit Taq DNA polymerase (Promega, Madison, Wis.) and 10× PCR buffer [100 mm Tris- $\mathrm{HCl}$ (pH 8.0), 15 mm MgCl $2,500 \mathrm{~mm} \mathrm{KCl]}$.
Preselective PCR amplifications ( 28 cycles) were performed as follows; $30 \mathrm{~s}$ at $94{ }^{\circ} \mathrm{C}, 30 \mathrm{~s}$ at $56^{\circ} \mathrm{C}$, and $60 \mathrm{~s}$ at $72{ }^{\circ} \mathrm{C}$.

The selective PCR amplifications were performed in $20 \mu \mathrm{L}$ reaction volumes each of which contained $2.5 \mu \mathrm{L}$ diluted (1:10) preamplified DNA template, $4.4 \mu \mathrm{L} \mathrm{MseI} \mathrm{primer}(6.7 \mathrm{ng} / \mu \mathrm{L})$, dNTPs (200 $\mu \mathrm{M}$ each), $0.4 \mu \mathrm{L}(0.5 \mathrm{pmol})$ of IRD700-label EcoRI primer (LI-COR, Lincoln, Neb.), and 1 unit of Taq polymerase, in $10 \times$ PCR buffer [100 mm Tris-HCl ( $\mathrm{pH} 8.0$ ), $15 \mathrm{~mm} \mathrm{MgCl}_{2}, 500$ $\mathrm{mm} \mathrm{KCl]}$. The conditions for selective PCR amplifications were as follows; 12 cycles of $30 \mathrm{~s}$ denaturation at $94{ }^{\circ} \mathrm{C}, 30 \mathrm{~s}$ at $65^{\circ} \mathrm{C}$ $\left(-0.7{ }^{\circ} \mathrm{C} /\right.$ cycle $)$ until reaching an annealing temperature of $56^{\circ} \mathrm{C}$, and extension for $60 \mathrm{~s}$ at $72{ }^{\circ} \mathrm{C}$. This was followed by an additional 28 cycles of $30 \mathrm{~s}$ at $94^{\circ} \mathrm{C}, 30 \mathrm{~s}$ at $56^{\circ} \mathrm{C}$, and $60 \mathrm{~s}$ at $72^{\circ} \mathrm{C}$.

All PCR reactions were conducted in a thermal cycler (GeneAmp PCR System 9600; Perkin-Elmer Corp., Foster City, Calif.). PCR amplification fragments were separated by electrophoresis in $6.5 \%$ polyacrylamide using a DNA sequencer (Long ReadIRTM 4200L1; LI-COR protocols, http://www.bio.licor.com\pubslbiopublhtm; LI-COR, Lincoln, Nebr.).

DATA ANALYSIS. Gel images were recorded during electrophoresis and analyzed with Gene ImagIR software (LI-COR, version 3.55). AFLP markers were scored for the presence $(1)$ or absence $(0)$ of bands. Data were analyzed (NTSYS-PC software version 2.0; Rohlf, 1993 ) in two steps. Similarity values were calculated using Dice's coefficients of similarity (Sneath and Sokal, 1973). A dendrogram was then constructed based on the matrix of the similarities using the Unweighted Paired Group Method (UPGMA) (Sneath and Sokal, 1973). An Analysis of Molecular Variance (AMOVA) was also used to estimate variance attributed to among and within genotypic groups (Huffetal., 1993). Genetic distances for the AMOVAanalysis were estimated using the Euclidean metric distance of Excoffier et al. (1992) defined as $E=n\left[1-2 n_{x y} / 2 n\right]$, where $2 n_{x y}$ is the number of markers shared by two individuals, and $\mathrm{n}$ is the total number of polymorphic markers. The AMOVA analysis was performed using WINAMOVA 1.55 software (Excoffier et al., 1992).

\section{Results}

Morphological Characterization. Hypogynous flowers were found on 'Big Blue', 'Christmas Tree', 'Densiflora', 'Evergreen Giant', 'John Birch', 'King Felix', 'Monroe White', 'Royal Purple', 'Samantha', 'Silver Dragon', 'Silver Midget', spicata, and 'Variegata', affirming their inclusion in the genus Liriope (Fig. 1a). Perigynous or hemi-epigynous flowers were found on aztecgrass and black mondo, affirming their inclusion in Ophiopogon (Fig. 1b). Three of the 18 cultivars seldom produced flowers. Undeveloped flowers of variegated mondo were found on one plant and are best described as hemi-epigynous. No flowers were found on minimondo; mondograss had some undeveloped inflorescences, but no flowers were found during our evaluation period.

Molecular CHARACTERIZATION. A total of 344 polymorphic AFLP markers (65 bp to $160 \mathrm{bp}$ ) were scored from four primer combinations (E-AAG/M-CTT, E-AAG/M-CTG, E-AAG/MCAG, E-AAG/M-CTA); discrimination between AFLP markers was poor outside of this size range. The number of AFLP markers per genotype ranged from 64 ('Christmas Tree') to 94 ('Samantha' and 'Silver Dragon') with a mean of 78.

The 344 polymorphic AFLP markers were sufficient to differentiate all 18 taxa (Fig. 2). Similarity values ranged from 0.23 to 0.57 (data not shown). The highest level of similarity (0.57) was between two groups of Liriope spp. cultivars, Big Blue/Silver Dragon and Samantha/Variegata, and the lowest was a group of 


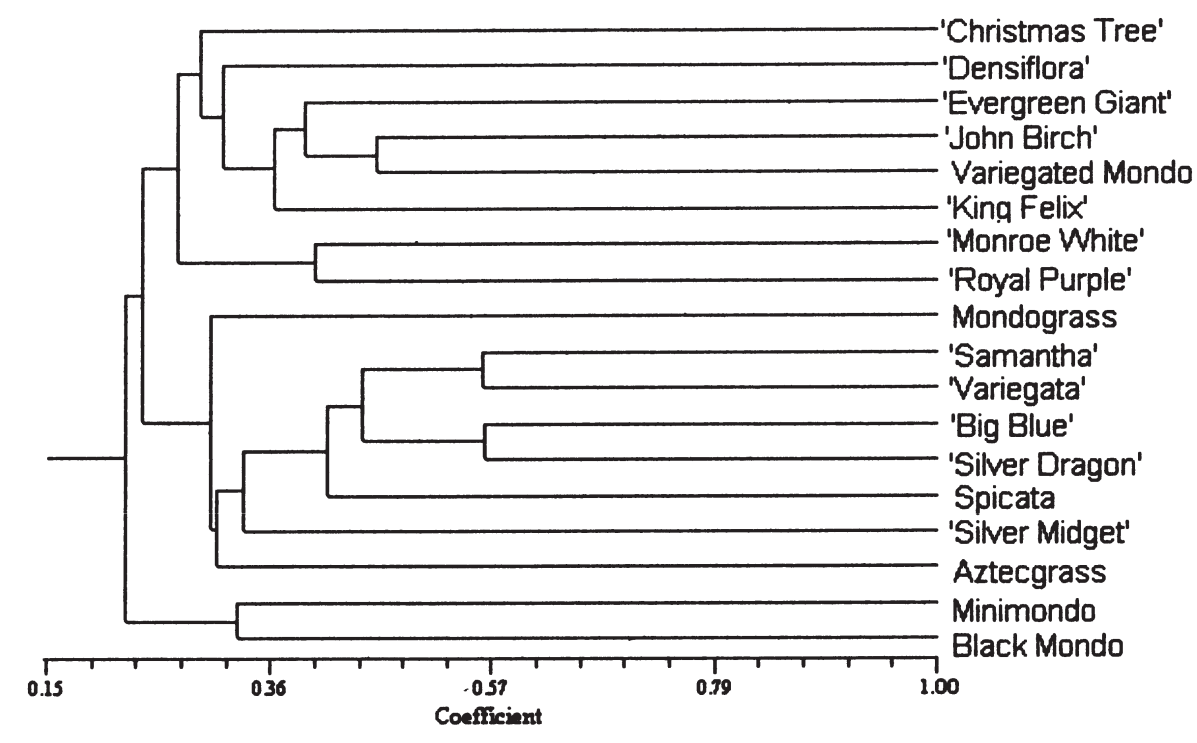

Fig. 2. UPGMA based dendrogram of 18 Liriope and Ophiopogon taxa. The numerical scale indicates increasing genetic similarity.

two mondograsses (black mondo and minimondo) and all other taxa (0.23), including other mondograsses.

The AFLP marker-based UPGMA dendrogram (Fig. 2) depicts the relationships between individual plants. The goodness-of-fit was $\operatorname{good}(r=0.83)$. Liriope taxa mostly showed similarity. Ophiopogon taxa were poorly grouped, exemplified by variegated mondo.

A number of different groupings were analyzed using AMOVA, e.g., Liriope taxa with and without variegated mondo, and variance components were estimated. The majority of the total genetic variability present was attributed to within group effects and was estimated to be $>95 \%$. The among group variance component accounted for $<5.0 \%$ of the total variability using various grouping strategies, but none showed significance $(P \leq 0.05)$.

\section{Discussion}

Floral structure mostly affirmed previous industry perceptions that 'Big Blue', 'Christmas Tree', 'Densiflora', 'Evergreen Giant', 'John Birch', 'King Felix', 'Monroe White', 'Royal Purple', 'Samantha', 'Silver Dragon', 'Silver Midget', spicata, and 'Variegata' belong to the genus Liriope based on the Convallariaceae generic key in Conran and Tamura (1998) (Fig. 1a). Flowers were less common on putative Ophiopogon taxa. Flowers were absent on minimondo and mondograss. Only aztecgrass (Fig. 1b) and black mondo had perigynous flowers. Variegated mondo flowers were best described as hemi-epigynous, i.e., somewhat intermediate between the two classes in morphology.

All taxa used in this study were different genetically from one another based on polymorphic molecular marker profiles (Fig. 2). Morphological approaches alone are incapable of differentiating the $\approx 100$ named cultivars (Fantz, 1993), underscoring the value of a molecular marker approach for identification.

Genetic distances estimated from the molecular marker data showed little differentiation between taxa identified as Liriope spp. and Ophiopogon spp. (Fig. 2). Although trends are observable, i.e., cultivars tend to group based on genera, no significant groups existed based on AMOVA $(P \leq 0.05)$. Most notable among the cultivars is variegated mondo. It tends to group more closely with Liriope spp. taxa than to Ophiopogon spp. taxa. Also, mor- phological data showed variegated mondo had an intermediate floral structure between the genera. This cultivar may represent an intergeneric hybrid, if a distinction actually existed between these two genera. Cutler (1992) used various morphological characteristics to differentiate among five species of Liriope and 12 species of Ophiopogon. Using mostly crystal types, cuticular sculpting on cells adjacent to stomata, and leaf width, Cutler(1992) was able to assign various voucher materials to species. Yet, Cutler (1992) stated "There appear to be no anatomical reasons for regarding Liriope and Ophiopogon as separate taxa." Rudall et al. (2000) found morphological differentiation between the two genera significant, but did not find differentiation based on molecular data, substantiating, in part, the findings of our current study. Rudall (2000) also concluded that these two genera "are clearly closely related to each other".

In conclusion, we found molecular marker data clearly differentiated the taxa from one another and showed that no duplicates existed in the samples of popular Liriopogon taxa investigated. Floral anatomy easily assigned taxa belonging to Liriope spp., but was less successful on Ophiopogon spp. taxa. Flowers were rare and ovary position less discernible on the latter. Most importantly, molecular marker data did not substantiate the existence of two genera. These preliminary data suggest that close genetic affinity exists among representative Liriope and Ophiopogon spp. taxa and support a view that these genera are possibly one.

\section{Literature Cited}

Adams, G. 1989. Great ground covers. Amer. Nurseryman 170:83-91.

Conran, J.G. and M.M. Tamura. 1998. Convallariaceae, p. 186-198. In: K. Kubitzki (ed.). The families and genera of vascular plants. SpringerVerlag, Berlin.

Cutler,D.F. 1992. Vegetative anatomy of Ophiopogoneae(Convallariaceae). Bot. J. Linnean Soc. 110:385-419.

Excoffier, L., P.E. Smouse, and J.M. Quattro. 1992. Analysis of molecular variance inferred from metric distances among DNA haplotypes: Application to human mitochondrial DNA restriction data. Genetics 131: 479-491.

Fantz, P.R.1994. A taxonomic research update of cultivated Liriopogons. HortTechnology 4:46-48.

Fantz, P.R. 1993. Taxonomic problems in cultivated Liriopogons. HortTechnology 3;146-149.

Huff, D.R., R. Peakall, and P.E. Smouse. 1993. RAPD variation within and among natural-populations of outcrossing buffalograss (Buchloe dactyloides (Nutt) Engelm). Theor. Appl. Genet. 86:927-934.

Liberty Hyde Bailey Hortorium. 1976. Hortus third: A concise dictionary of plants cultivated in the United States and Canada. Macmillan, New York.

Rohlf,F.J. 1993. NTSYS-pc numerical taxonomy and multivariate analysis system. Version 1.8. Exeter Publ., Setauket, N.Y.

Rudall,P.J., J.G. Conran, and M.W. Chase. 2000. Systematics of Ruscaceae/ Convallariaceae: a combined morphological and molecular investigation. Bot. J. Linnean Soc. 134:73-92.

Skinner, H.T. 1971. Some liriopogon comments. J. Royal Hort. Soc. 96 345-350.

Sneath, P.H.A. and R.R. Sokal. 1973. Numerical taxonomy. The principles and practice of numerical classification. W.H. Freeman, San Francisco.

Vos, P., R. Hogers, M. Bleeker, M. Reijans, T.van de Lee, M. Hornes, A. Frijters, J. Pot, J. Peleman, M. Kuiper, and M.Zabeua. 1995. AFLP; a new technique for DNA fingerprinting. Nucl. Acids Res. 23:4407-4414. 